\title{
Early planting, management of edges and non-crop habitats reduce potyvirus infection in maize
}

\author{
Gemma Clemente-Orta ${ }^{1} \cdot$ Ramon Albajes $^{1} \cdot$ Maria Angeles Achon ${ }^{1}$ \\ Accepted: 21 May 2020 / Published online: 18 June 2020 \\ (C) INRAE and Springer-Verlag France SAS, part of Springer Nature 2020
}

\begin{abstract}
Viruses are a limiting factor in maize production areas around the world. The knowledge of the interactions between agroecosystems and the virus-vector-host system is limited, but a landscape-scale approach could help fill this gap. In this study, we show how the use of multiple spatial scales, i.e. 200,500 and $1000 \mathrm{~m}$, is a novel methodology for explaining the incidence of two closely related potyviruses: maize dwarf mosaic virus and sugarcane mosaic virus. To determine the factors involved in virus incidence, we recorded the proportion of surrounding crops and non-crop habitats at the landscape scale and, at the field scale, we recorded the planting date, the maize field area, the crop rotation and the weed diversity in the edges. In addition, we estimated the numbers of aphids with sticky yellow traps. Virus incidence in maize and in alternative grass hosts was determined by DASELISA. Generalised linear mixed models were fitted using the multimodel inference method. The results showed that the most predictive model for the incidence of both potyviruses was at a scale of $200 \mathrm{~m}$, but for the aphid abundance, it was at a scale of $500 \mathrm{~m}$. Maize dwarf mosaic virus incidence was most affected by field management, and sugarcane mosaic virus by landscape variables. The planting date and the weed diversity in the edges were the field variables with the highest positive effects on both potyviruses. Moreover, both viruses were positively related to the abundance of aphids, and maize dwarf mosaic virus was only related to the cover of Johnson grass in the edges. Non-crop habitats had negative effects on potyvirus incidence at all spatial scales, showing that biodiversity in the landscape decreases the incidence of viruses. Here, we show that the early planting, the management of edges and the presence of non-crop habitats are key factors.
\end{abstract}

Keywords Maize virus $\cdot$ Aphids $\cdot$ Planting date $\cdot$ Alternative host $\cdot$ Non-crop habitats $\cdot$ Agricultural landscape $\cdot$ Sustainable crop protection

\section{Introduction}

Many factors have driven the emergence of diseases in plants: human demographics and behaviours, the global trade, the increase in the agricultural surface worldwide (i.e. ecological changes, economic development and land use), the introduction of invasive pathogens and climate change. Viruses account for $47 \%$ of emerging infectious diseases in plants and are the second most important group of plant pathogens that cause high losses, mainly in intensive agricultural crops (García-Arenal and McDonald 2003; Anderson et al. 2004).

Gemma Clemente-Orta

gemma.clemente@pvcf.udl.cat; gco5150@gmail.com;

gemma.clemente@udl.cat

1 Department of Crop and Forest Sciences, AGROTECNIO Center, University of Lleida, Rovira Roure 191, 25198 Lleida, Spain
With technification in agriculture systems, insect pests, fungi or weeds can be controlled by management programs, but viral diseases are more difficult to control because there is no direct product against viruses. Moreover, the oversimplification of crop diversity, reduced genetic diversity, intensive farming systems and the increasing use of phytosanitary products have reduced the ecological functions of agroecosystems and could promote changes in the epidemiology of diseases (Stukenbrock and McDonald 2008).

The host plant, vector and virus are interdependent components of a complex pathosystem. The effect of biodiversity on the ability of viruses to infect their host plant and cause disease is a major question in plant pathology that is central to understanding the emergence of infectious diseases and developing strategies for their management (Pagán et al. 2012). Keesing et al. (2006) postulated that reduced biodiversity can increase disease incidence as a result of the increased abundance of susceptible major hosts, thus facilitating disease spread, which 
is known as the "dilution effect" hypothesis. The spread of infectious diseases is inherently a spatial process often embedded in physically complex landscapes (Biek and Real 2010). However, little is known about the linkage between spatial processes at the landscape scale, the ecology of vector colonisation and the virus transmission rate in the epidemiological disease process (Meentemeyer et al. 2012). In agroecosystems, crop viruses need to persist locally in a host plant with long life history stages or in an alternative weed host to ensure the temporal availability of inoculum in the landscape (Malmstrom et al. 2011). Thus, the local abundance of long-lived hosts, the host range and the movement of vectors are the key factors controlling infection risk (Borer et al. 2010; McLeish et al. 2017). Specifically, the behaviour and biology of vectors determine the incidence of viruses within geographical areas in the following manners: (1) the abundance of vectors coincides with virus-infected plants (crop or alternative weed hosts), (2) a moderate abundance of vectors coincides with a large number of virus-infected plants or (3) large numbers of both vectors and virus-infected plants coincide.

Since the 1980s, maize fields in Spain have been subject to severe losses, highlighting viruses as one of the main causes limiting their production. Maize dwarf mosaic virus (MDMV) is endemic in the Ebro Valley (Spain) (Achon et al. 1994), and the occurrence of sugarcane mosaic virus (SCMV) has increased since its detection in 2002 (Achon and Alonso-Dueñas 2009). MDMV and SCMV are included in the sugarcane mosaic virus subgroup (Potyvirus genus, Fam. Potyviridae) and the nucleotide sequences of isolates detected in Spain differed from each other by $31 \%$ (Achon et al. 2007). Both viruses are transmitted in a non-persistent manner by more than 15 species of aphids (Ford and Tosic 1989; Teakle et al. 1989) and by seeds at a low rate $(<0.5 \%)$. The host range of MDMV and SCMV is constrained to Poaceae, including maize and sorghum, the crops with the highest economic importance. Despite the large number of grasses reported as experimental hosts, alternative hosts in natural conditions are limited (Ford and Tosic 1989; Teakle et al. 1989; Achon and Sobrepere 2001; Achon and Alonso-Dueñas 2009). Sorghum halepense (L.) Pers. (Johnsongrass) is the perennial reservoir for MDMV in Spain, and Setaria verticillata (L.) ands Digitaria sanguinalis (L.) Scop. are annual summer grasses infected with this virus in the field (Achon and Sobrepere 2001; Achon and Alonso-Dueñas 2009). To date, Setaria verticillata has been the only alternative host detected for SCMV in Spain (Achon and Alonso-Dueñas 2009). No winter reservoirs have been found for SCMV, although the potential capacity of species of the genera Bromus, Cynodon and other winter annual grasses has been demonstrated under field conditions (Hohmann et al. 1998; Oertel et al. 1999).
In our study area, Ebro Valley, the number of aphids colonising maize is closely linked to migrations of these species from winter cereals (Pons et al. 1994). Thus, increasing the amount of winter cereal might directly increase aphid abundance due to the resource concentration effect (Root 1973), especially in landscapes dominated by cereals. The amount of virus host habitats and their connectivity may influence the global infection pressure in certain areas. However, knowledge of larger-scale interactions among host spatiotemporal heterogeneity, environmental conditions, and the rates at which pathogens disperse through and among fragmented host populations is limited until now (Meentemeyer et al. 2012). We take into account this perspective and conducted our study under a landscape perspective in combination with field variables of crop management. During two consecutive years, we selected 46 commercial maize fields located in areas with different proportions of cereals in the landscape each year. We quantified the landscape composition at three spatial scales (i.e. $200 \mathrm{~m}, 500 \mathrm{~m}$ and $1000 \mathrm{~m}$ ) within concentric cycle buffers. To further extend the knowledge of infection risk drivers in northeast Spain, we asked the following questions: (1) what are the main drivers of maize infection risk by MDMV and SCMV under different landscape and field variables? (2) Does the main driver of infection risk vary over different landscape scales? (3) What is the best explanatory spatial scale to elucidate the infection risk of two closely related potyviruses?

\section{Materials and methods}

\subsection{Study area}

This study was carried out during 2016 and 2017 in the Ebro Basin in NE Spain $\left(41^{\circ} 48^{\prime} 12.20^{\prime \prime}\right.$ N, $0^{\circ} 32^{\prime} 45.77^{\prime \prime}$ E; 120-346 m altitude; 200-400 mm rainfall, Tmin 8-24 ${ }^{\circ} \mathrm{C}$ and Tmax $18-38{ }^{\circ} \mathrm{C}$ ) (Fig. 1a). The agroecosystem has been classically dominated by field crops; alfalfa rotates with winter (from December to June) and summer cereals (from April to November) mainly maize. Recently, commercial demand has led to an increase in the stone fruit orchard surface in some areas, leading to an intensiveproduction agroecosystem in this region. Crops are interspersed with scattered patches of non-crop habitats (nonproductive areas, long fallows, semi-natural habitats and repopulated forest). Common pest management practices in cereals include pre- and post-emergence herbicide applications and cereal seed treatment with both insecticides and fungicides. The management of alfalfa consists of 5/6 cuttings during the productive period (March-October), and the crop is in the field for 4-5 years. 



Fig. 1 a Agricultural landscape in northeastern Spain. b Landscape sampled in 2016 and 2017. The proportion of cereals (grey) and non-crop habitats (black) vary among the scale chose in the study (radii of $200 \mathrm{~m}, 500 \mathrm{~m}$ and $1000 \mathrm{~m}$ )

\subsection{Factors measured at the field level}

\subsubsection{Maize field variables}

During the 2 years of the study, we selected 46 maize fields with a gradient of winter and summer cereal proportions in the surrounding landscapes. Some of the selected maize fields were not the same each year due to crop rotations. The size of the maize fields where virus incidence was measured varied between 0.9 and 13.68 ha, and they were separated from each other by at least $2 \mathrm{~km}$. The agricultural landscape covered by the selected fields was $700 \mathrm{~km}^{2}$ (Fig. 1b). The following explanatory maize field variables were included in the analysis: maize field surface (ha), planting date (number of weeks from January) and rotation/not rotation (with winter cereal).

\subsubsection{Maize surveyed}

The survey for virus incidence was conducted at maize anthesis following the scheme described in Achon and Sobrepere (2001). 
In each field, we systematically collected 30 maize plants following a W-shaped pattern. The distance between plants varied according to maize field size. In addition, we collected at least two grass plants reported in the literature as potential virus hosts that were located inside of the maize field. Maize samples consisted of the two youngest leaves of the plant, and grass samples consisted of the leaves or the entire plant. In each field, each sample was placed in a separate plastic bag, grasses were identified at the species level, and maize and grasses were examined for virus-like symptoms or no symptoms. All samples were stored at $-80^{\circ} \mathrm{C}$ until virus identification.

\subsubsection{Edge surveys for weeds and grass collection}

Floristic surveys were conducted in the edges of the 46 maize fields surrounded by crops or non-crops areas during MayJune in the 2 years. To determine the abundance and composition of plant species in the edges, especially the species of grasses, we carried out surveys in edge areas when the maize was at an early growth stage or recently sown. For each sampling point, the cover-abundance of weed species was recorded using the Braun-Blanquet scale (1979) in three rectangular plots $\left(2 \times 5 \mathrm{~m}^{2}\right)$ along the edges. The number of edges surveyed in each landscape was between 2 and 6 but depended on the number of different crops and non-crop habitats close to the sampled maize field. For instance, in very diverse landscapes, we sampled six edges: maize-orchard, maize-alfalfa, orchard-alfalfa, maize-maize, orchard ground cover and noncrop habitats. Then, the cover-abundance values were transformed into the mean value of the percent cover of each field, and the Shannon index $(\mathrm{H})$ was calculated:

$H=-\sum_{i=1}^{46} \pi_{i} \times \ln \pi_{i}$

where ' $\pi$ ' is the proportional abundance of species, and ' $i$ ' is the number of observations. Johnson grass plant cover and $H$ were the explanatory field variables in the models.

In addition, for information about the cover plants and diversity groups of the edges, we used floristic surveys to transform the cover-abundance of species into the mean value of the percent cover according to six types of edges sampled to calculate the Shannon index and grouped the recorded plant species as dicotyledons or monocotyledons (Fig. 2a). These variables were only descriptive and are not included in the analysis.

Furthermore, to detect edge grasses as an alternative host of virus inoculum, we collected samples in the surveyed edge plots mentioned above according to the following criteria: (1) two samples of the most abundant grass, (2) one sample of the second most abundant grass, (3) two samples of the least frequent grass species and (4) if present, one Johnson grass plant exhibiting virus-like symptoms (leaf mosaic). In each field, each sample was placed in a separate plastic bag, identified at the species level and examined for virus-like symptoms or no symptoms. All samples were stored at -80 ${ }^{\circ} \mathrm{C}$ until virus identification.

\subsubsection{Virus detection}

Virus identification of maize and grass leaf samples were performed by the double antibody sandwich enzyme-linked immunosorbent assay (DAS-ELISA) (Adams and Clark 1977) using polyclonal antisera against MDMV and SCMV (Loewe GmbH). Commercial antisera were used at the dilution and in the buffers recommended by the manufacturer. Samples were extracted (1:20 g/ml of fresh tissue and 1:100 of died tissue) by grinding with a mortar and pestle. Extracts from healthy maize and Johnson grass plants were used as negative controls, and extracts of MDMV-Sp and SCMV-Sp were used as positive controls. Samples were considered positive when the $A_{405 \mathrm{~nm}}$ values were three-fold higher than the negative controls on the same plate.

\subsubsection{Aphid sampling}

Aphids were collected in the field between the maize phenological stages V3 (vegetative growth) to VT (reproductive development-anthesis) using yellow sticky traps $(30 \times 25$ $\mathrm{cm}$, Serbios, Badia Polesine, Italy). In each field, we placed 3 traps on stakes at the crop canopy height along a transect perpendicular to the nearest edge (approx. $30 \mathrm{~m}$ ). The traps were separated from each other by $15 \mathrm{~m}$ and left for 7 days. Then, the traps were collected and stored at $6-8{ }^{\circ} \mathrm{C}$ until insect identification and recording. The number of aphids caught on each trap was counted under binocular conditions in the lab.

\subsection{Factors measured at landscape scales}

Data on the landscape composition were obtained for both years from Instituto Geográfico Nacional (IGN) and Declaració única agrària (DUN) of Generalitat de Catalunya, Spain. ArcGIS software was used to identify four types of land use: orchard, cereals, alfalfa and non-crop habitats. Then, the proportions of each type of land in the landscape surrounding the central point of each maize field within radii of $200 \mathrm{~m}, 500$ $\mathrm{m}$ and $1000 \mathrm{~m}$ were calculated (Fig. 1b). Autocorrelation can be a problem for classical statistical tests, which rely on independently distributed errors, as it may lead to erroneous conclusions on the significance of covariates in studies of speciesenvironment relationships. Thus, the correlations among the four land use variables in all the fields were assessed using Spearman rank correlation coefficients. These analyses showed that the proportions of cereals and orchards in the landscape were negatively correlated in the three spatial scales (Spearman's rho $\geq 0.71$ ); therefore, the proportion of orchards was excluded to build the models according to the criteria of Campbell and Swinscow (2009). 


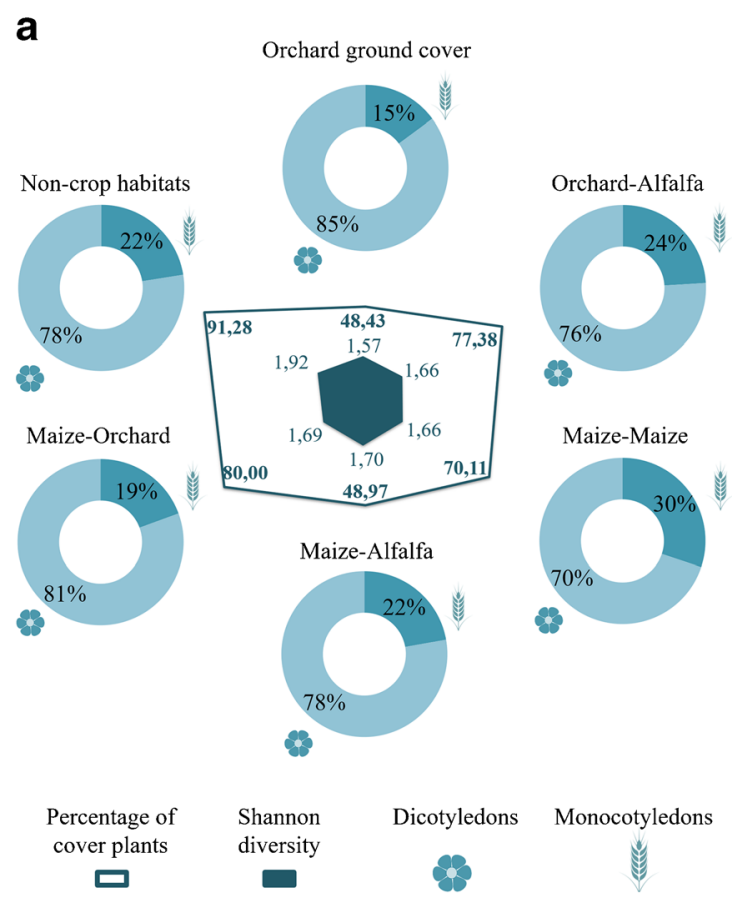

Fig. 2 a The composition of plant species in edges was estimated by the Braun-Blanquet scale. The cover-abundance values were transformed into the mean value of the percent cover according to the six types of edges sampled. The radar graph represents the mean percentage of the plant edge cover in sampled maize fields and $\mathrm{H}$ according to the field

\subsection{Data analysis}

We used multimodel inference (MuMIn package, Bartoń 2018), a procedure that fits models using all possible combinations of predictors and weights them using the Akaike information criterion (AIC) (dredge function). This method allows the data-based selection of a "best" model and the ranking and weighting of the remaining models in a pre-defined set. This procedure generated AIC values and Akaike weights for each candidate model. Model averaging was performed on the set of $\Delta \mathrm{AICc}<2$ criteria. The selection of a best approximating model represents an inference from the data and tells us what "effects" (represented by parameters) can be supported by our data.

First, we used Moran's I statistic for the spatial autocorrelation (measure of the correlation of a variable with itself through space) of the incidence of MDMV, SCMV and aphid abundance. The results indicated that there was no significant spatial autocorrelation (MDMV Moran's $I=-0.015, p=0.92$; SCMV Moran's $I=-0.007, p=0.83$; aphid Moran's $I=-0.014, p=$ 0.89 ). Second, the landscape and field metrics for each model were standardised (mean centred and scaled). Third, to analyse the relationships between the incidence of MDMV, SCMV, and aphid abundance with the field and landscape variables, we used a generalised linear mixed model (GLMM) in R within the lme4 package. After that, models were fitted following the different spatial scales mentioned above: 200,500 and $1000 \mathrm{~m}$ from the selected maize fields. We used the percentage of viral incidence b
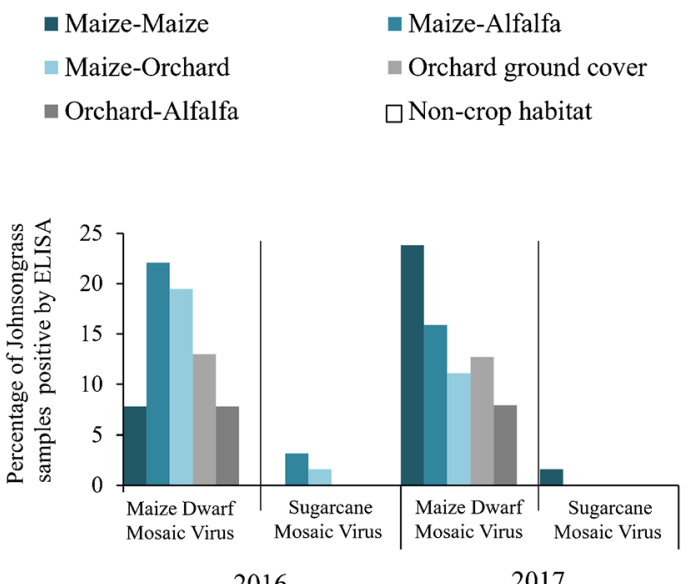

edge of the neighbouring crop. Circles represent the flora grouped into dicotyledons and monocotyledons. b Percentage of Johnson grass samples positive with maize dwarf mosaic virus (MDMV) and sugarcane mosaic virus (SCMV) antisera by DAS-ELISA in maize field edges and surrounding habitats.

in each field, including the weight of the variable (number of maize samples per field), to analyse the effects. In the virus (percentage of vital incidence) and aphid (vector abundance) models, the planting date, maize field area, crop rotation, $\mathrm{H}$ in the edges, percentage of Johnsongrass plants in the edges and proportions of alfalfa, cereals and non-crop habitats were included as fixed factors, and in the virus models, the sum of aphids was also included. The year was included as a random factor in all models. The models of viruses were fitted using glmer (for the binomial distribution), and the abundance of aphids was fitted using glm.nb (for the negative binomial distribution) using the $\mathrm{R}$ package MASS (Ripley 2019). Then, models of virus incidences residuals were graphically inspected with qqplot and histogram graphics to ensure there was no violation of normality and homoscedasticity assumptions. Finally, in the virus models, the relative importance of each predictor variable was plotted to check the weight of the variables included in the best model.

\section{Results and discussion}

\subsection{Incidence of MDMV and SCMV in maize fields}

Virus incidence in the maize fields was determined using serological analyses of 1324 maize plants collected in the systematic surveys. Virus incidence varied significantly between the two years for both viruses, that is, $\operatorname{MDMV~}\left(F_{1,45}=5.09, p\right.$ 
$=0.03)$ and $\operatorname{SCMV}\left(F_{1,45}=7.10 p=0.01\right)$. The highest incidence of MDMV and SCMV was observed in 2016 (24\% and $28 \%$, respectively). In 2017, the incidence decreased notably, with values of 7\% for MDMV and 6\% for SCMV. Moreover, the highest incidences were detected in fields sown later in the year (from May to end of June) with values of $22 \%$ of MDMV and $23 \%$ of SCMV compared with early sown (from March to end of April) $10 \%$ of MDMV and 12\% of SCMV. In the study period compared with previous years, the overall incidence of SCMV in the Ebro Valley increased by $13.8 \%$, and the MDMV remained at a similar level (Achon and Sobrepere 2001; Achon and Alonso-Dueñas 2009). The increasing incidence of SCMV in the last years is in concordance with the predictions of Achon and Alonso-Dueñas 2009 from the first increasing detection during 1997-1999 (Achon and Sobrepere 2001). Albeit other factors could not discard, the increased incidence of SCMV may be the result of the greater susceptibility of the current maize varieties grown in the study area (Achon and Alonso-Dueñas, unpublished results). In addition, we found a high correlation between the incidence of both viruses within the same year $\left(R^{2} 0.94, p \leq 0.001 ; \mathrm{df}=45\right)$.

The grass species found and collected within the maize field were Johnson grass, Setaria spp., Cynodon dactylon (L.) Pers. and Echinochloa crus-galli (L.) P.B. Although these samples were not considered in the virus incidence models, a total of 66 grass samples were analysed using DAS-ELISA. Only Johnson grass was infected with MDMV (39.29\% of samples in 2016 and 57.14\% of samples in 2017), and unexpectedly, one sample was infected with both SCMV and MDMV in 2016. These results confirm that Johnson grass continues to be the main perennial reservoir of MDMV, as Achon and Sobrepere (2001) reported, but may also be an inoculum source of SCMV, a role that has not been reported before in our area. Thus, the perennial character of Johnson grass is important to the role of this weed as a virus host as virus infection risk increases with increasing local abundance of the perennial grass (Borer et al. 2010).

\subsection{Plant diversity and alternative hosts of MDMV and SCMV in maize edges and surrounding habitats}

A total of 203 plant species were identified in the 504 sampling points in the edge surveys. The maximum plant cover and $H$ were detected in the edges of non-crop habitats (Fig. 2a), but none plant collected in this habitat resulted infected with the two viruses. On the other hand, the proportion of monocotyledons, the only potential virus reservoirs, was highest in edges between maize-maize fields (Fig. 2a). Of the 203 plants sampled, $12 \%$ of the species identified were grasses, among which the most abundant species were Hordeum murinum L., Cynodon dactylon, Bromus diandrus (L.), Poa annua L., Johnsongrass, Avena sterilis L., Bromus catharticus Vahl. and Lolium rigidum Gaudin.
During the edge survey, we collected a total of 641 grasses belonging to 25 species reported as a host, possible host or potential anecdotic host that were analysed by DAS-ELISA for MDMV and SCMV (Table 1). Specifically, high abundances of Johnson grass were found in all surveyed edges, in alfalfa fields around sprinklers and in the ground cover of orchards. Although the management of edges includes herbicide treatments and/or mechanical labour, during samplings in the study, we observed that Johnson grass was particularly present and frequently exhibited mosaic virus symptoms in the edges and the base of sprinklers. A total of 110 samples of Johnson grass were positive with MDMV (approximately $75 \%$ of the samples), although there were variations among edges and years (Fig. 2b). Although Johnson grass was abundant around alfalfa sprinklers and hosted abundant aphids, only 1 of the 9 Johnson grass samples collected in this situation was infected with MDMV. In addition, 1 of the 69 samples of $C$. dactylon and 1 of the 37 samples of B. catharticus were positive for MDMV (Table 1); these species have not been reported as MDMV hosts until now (Achon and Sobrepere 2001; Achon and Alonso-Dueñas 2009). This is a remarkable result for the virus epidemiology given that both species are particularly abundant and multiannual, increasing the host range in our agroecosystem (McLeish et al. 2017).

Concerning SCMV, we found 4 positive samples of Johnson grass, representing $0.8 \%$ and $2 \%$ of the samples in 2016 and 2017, respectively; these percentages were much lower than those observed for MDMV. Moreover, three samples with mixed MDMV and SCMV infections were detected (4\% of Johnson grass samples in 2016) (Table 1, Fig. 2b). No previous Johnson grass samples positive for SCMV had been detected in our area, but this species is among the most persistent weeds (Peerzada et al. 2017), and it has been positively detected as an SCMV host in another Mediterranean country (Moradi et al. 2017). Although Achon and Alonso-Dueñas (2009) reported positive samples of Setaria verticillata with SCMV, no evidence of grass hosts for SCMV other than Johnson grass was found in this study when we analysed 641 grass samples belonging to 25 species. This could be because the edge areas we sampled in spring, Setaria spp. showed a low cover because it is a summer grass. However, the results of our random edge survey to find Johnson grass plants positive with SCMV and the high incidences observed on maize in our study suggest that the long duration of the life history stages of this specie make it a potential alternative host that ensures the temporal availability of inoculum in the landscape. Although it has been reported in other countries that species of the genera Bromus, Cynodon and other winter annual grasses could act as hosts in the absence of maize, many samples of these genera in this study were negative for SCMV. Thus, the low occurrence of the winter host of SCMV continues to be the bottleneck in the epidemiological knowledge of this potyvirus. These results suggest more 
Table 1 Relation of grasses collected in edge surveys and analysed by DAS-ELISA. Data in the 'host' column were taken from the literature. ***host, **possible host, *anecdotic species; A: annual species, P: perennial species. The three right columns show the number of plants that reacted with antisera of the plants collected for analysis. The numbers in parentheses represent the percentages of ELISA-positive samples for MDMV and SCMV

\begin{tabular}{|c|c|c|c|c|c|c|}
\hline \multirow[t]{2}{*}{ Year } & \multirow[t]{2}{*}{ Grass species collected } & \multirow[t]{2}{*}{ Host } & \multirow[t]{2}{*}{ Growth habitat } & \multicolumn{2}{|c|}{ Reacted with antisera } & \multirow[b]{2}{*}{ Double infection } \\
\hline & & & & MDMV & SCMV & \\
\hline \multirow[t]{23}{*}{2016} & Avena sativa $\mathrm{L}$. & $* *$ & $\mathrm{~A}$ & $0 / 1(0)$ & $0 / 1(0)$ & $0 / 1(0)$ \\
\hline & Avena sterilis L. & $* *$ & A & $0 / 58(0)$ & $0 / 58(0)$ & $0 / 58(0)$ \\
\hline & Brachypodium phoenicoides (L.) & $* *$ & $\mathrm{P}$ & $0 / 27(0)$ & $0 / 27(0)$ & $0 / 27(0)$ \\
\hline & Bromus catharticus Vahl. & $* *$ & $\mathrm{P}$ & $0 / 17(0)$ & $0 / 17(0)$ & $0 / 17(0)$ \\
\hline & Bromus spp. & $* *$ & $\mathrm{~A}$ & $0 / 32(0)$ & $0 / 32(0)$ & $0 / 32(0)$ \\
\hline & Cynodon dactylon (L.) Pers. & $* *$ & $\mathrm{P}$ & $1 / 45(2.22)$ & $0 / 45(0)$ & $0 / 45(0)$ \\
\hline & Dactylis glomerata L. & $*$ & $\mathrm{P}$ & $0 / 5(0)$ & $0 / 5(0)$ & $0 / 5(0)$ \\
\hline & Hordeum murinum L. & $* *$ & $\mathrm{~A}$ & $0 / 58(0)$ & $0 / 58(0)$ & $0 / 58(0)$ \\
\hline & Koeleria phleoides (Vill.) & $*$ & A & $0 / 2(0)$ & $0 / 2(0)$ & $0 / 2(0)$ \\
\hline & Lepturus repens (G.Forst.) & $*$ & A & $0 / 1(0)$ & $0 / 1(0)$ & $0 / 1(0)$ \\
\hline & Ligeum spartum (L.) Kunth & $*$ & $\mathrm{P}$ & $0 / 1(0)$ & $0 / 1(0)$ & $0 / 1(0)$ \\
\hline & Lolium rigidum Gaudin & $* *$ & $\mathrm{P}$ & $0 / 14(0)$ & $0 / 14(0)$ & $0 / 14(0)$ \\
\hline & Mellica celiata $\mathrm{L}$. & $*$ & $\mathrm{P}$ & $0 / 3(0)$ & $0 / 3(0)$ & $0 / 3(0)$ \\
\hline & Oryzopsis miliacea (L.) & $*$ & $\mathrm{P}$ & $0 / 9(0)$ & $0 / 9(0)$ & $0 / 9(0)$ \\
\hline & Phalaris arundinacea $\mathrm{L}$. & $*$ & $\mathrm{P}$ & $0 / 2(0)$ & $0 / 2(0)$ & $0 / 2(0)$ \\
\hline & Phalaris minor Retz. & $*$ & $\mathrm{P}$ & $0 / 2(0)$ & $0 / 2(0)$ & $0 / 2(0)$ \\
\hline & Poa аппиа $\mathrm{L}$. & $*$ & $\mathrm{~A}$ & $0 / 1(0)$ & $0 / 1(0)$ & $0 / 1(0)$ \\
\hline & Poa pratensis L. & $*$ & $\mathrm{P}$ & $0 / 2(0)$ & $0 / 2(0)$ & $0 / 2(0)$ \\
\hline & Polygonon sp. & $*$ & $\mathrm{P}$ & $0 / 2(0)$ & $0 / 2(0)$ & $0 / 2(0)$ \\
\hline & Setaria pumila (L.) & $* *$ & A & $0 / 1(0)$ & $0 / 1(0)$ & $0 / 1(0)$ \\
\hline & Setaria verticillata (L.) & $* *$ & A & $0 / 2(0)$ & $0 / 2(0)$ & $0 / 2(0)$ \\
\hline & Setaria viridis (L.) & $* *$ & A & $0 / 1(0)$ & $0 / 1(0)$ & $0 / 1(0)$ \\
\hline & Sorghum halepense (L.) & $* * *$ & $\mathrm{P}$ & $54 / 77(70.13)$ & $3 / 77(3.9)$ & $3 / 77(3.9)$ \\
\hline \multirow[t]{24}{*}{2017} & Avena barbata Pott & $* *$ & A & $0 / 3(0)$ & $0 / 3(0)$ & $0 / 3(0)$ \\
\hline & Avena sterilis L. & $* *$ & $\mathrm{~A}$ & $0 / 33(0)$ & $0 / 33(0)$ & $0 / 33(0)$ \\
\hline & Brachypodium phoenicoides (L.) & $* *$ & $\mathrm{P}$ & $0 / 10(0)$ & $0 / 10(0)$ & $0 / 10(0)$ \\
\hline & Bromus catharticus Vahl. & $* *$ & $\mathrm{P}$ & $1 / 20(5)$ & $0 / 20(0)$ & $0 / 20(0)$ \\
\hline & Bromus diandrus Roth & $*$ & $\mathrm{~A}$ & $0 / 16(0)$ & $0 / 16(0)$ & $0 / 16(0)$ \\
\hline & Bromus madritensis L. & $*$ & $\mathrm{~A}$ & $0 / 4(0)$ & $0 / 4(0)$ & $0 / 4(0)$ \\
\hline & Bromus spp. & $* *$ & $\mathrm{~A}$ & $0 / 7(0)$ & $0 / 7(0)$ & $0 / 7(0)$ \\
\hline & Cynodon dactylon (L.) Pers. & $* *$ & $\mathrm{P}$ & $0 / 24(0)$ & $0 / 24(0)$ & $0 / 24(0)$ \\
\hline & Echinochloa crus-galli (L.) P.B. & $* *$ & $\mathrm{~A}$ & $0 / 1(0)$ & $0 / 1(0)$ & $0 / 1(0)$ \\
\hline & Eragrostis spp. & $*$ & $\mathrm{~A}$ & $0 / 1(0)$ & $0 / 1(0)$ & $0 / 1(0)$ \\
\hline & Hordeum murinum L. & $* *$ & $\mathrm{~A}$ & $1 / 44(0)$ & $0 / 44(0)$ & $0 / 44(0)$ \\
\hline & Lolium rigidum Gaudin & $* *$ & $\mathrm{P}$ & $0 / 18(0)$ & $0 / 18(0)$ & $0 / 18(0)$ \\
\hline & Oryzopsis miliacea (L.) & * & $\mathrm{P}$ & $0 / 6(0)$ & $0 / 6(0)$ & $0 / 6(0)$ \\
\hline & Phalaris minor Retz. & * & $\mathrm{P}$ & $0 / 3(0)$ & $0 / 3(0)$ & $0 / 3(0)$ \\
\hline & Phleum paniculatum Huds. & $*$ & $\mathrm{~A}$ & $0 / 1(0)$ & $0 / 1(0)$ & $0 / 1(0)$ \\
\hline & Poa annua $\mathrm{L}$. & $*$ & $\mathrm{~A}$ & $0 / 6(0)$ & $0 / 6(0)$ & $0 / 6(0)$ \\
\hline & Poa pratensis L. & $*$ & $\mathrm{P}$ & $0 / 10(0)$ & $0 / 10(0)$ & $0 / 10(0)$ \\
\hline & Polygonon sp. & $*$ & $\mathrm{P}$ & $0 / 1(0)$ & $0 / 1(0)$ & $0 / 1(0)$ \\
\hline & Setaria pumila (L.) & $* *$ & $\mathrm{~A}$ & $0 / 1(0)$ & $0 / 1(0)$ & $0 / 1(0)$ \\
\hline & Setaria verticillata (L.) & $* *$ & A & $0 / 4(0)$ & $0 / 4(0)$ & $0 / 4(0)$ \\
\hline & Setaria viridis (L.) & $* *$ & A & $0 / 1(0)$ & $0 / 1(0)$ & $0 / 1(0)$ \\
\hline & Triticum spp. & $*$ & A & $0 / 1(0)$ & $0 / 1(0)$ & $0 / 1(0)$ \\
\hline & Sorghum halepense (L.) & $* *$ & $\mathrm{P}$ & $51 / 63(81)$ & $1 / 63(1.6)$ & $0 / 63(0)$ \\
\hline & Total samples & & & $105 / 641(16.4)$ & $4 / 641(0.62)$ & $3 / 641(0.46)$ \\
\hline
\end{tabular}

powerful detection methods, such as next-generation sequencing (NGS) tools, should be used in future research.

\subsection{Effects of landscape and field variables on the vectors of MDMV and SCMV}

Aphids are one of the primary pests in the cultivation of maize in Spain, with variable abundances seasonally and spatially (Pons et al. 1994; Asín and Pons 1999). During the 2-year study, a total of 240 traps were placed in 46 maize fields where 2684 aphids were recorded. The abundance of aphids varied significantly between years $\left(F_{1,45}=\right.$ $15.23, p \leq 0.001$ ). Aphids were notably more abundant in 2016 than in 2017 (2390 and 294 aphids, respectively). Moreover, the highest densities of aphids in June coincidence with the highest incidence of MDMV and SCMV in 
maize fields sown later (since the week number 25) (Fig. $3 \mathrm{~b}$, graph aphid abundance).

The most parsimonious model relating the aphid abundance with the landscape and field variables is shown in Table 2. Only significant variables of the best model are shown. Although the model at $500 \mathrm{~m}$ was slightly more predictive than the model at $200 \mathrm{~m}$, the two scales can be considered valid because the differences between their AIC values were less than 2 . At the scale of $500 \mathrm{~m}$, the aphid abundance on maize was also found to relate to some landscape variables in a study carried out recently in the area (Clemente-Orta et al. 2020). Moreover, in the model with a $200 \mathrm{~m}$ scale, an important relationship was found between the proportion of cereals in the landscape and the maize aphid abundance, although this effect was not detected at the two higher scales (i.e. 500 and $1000 \mathrm{~m}$ ). These results obtained at the landscape scale confirm that the colonisation of maize is closely linked to migrations of these species from nearby winter cereals, as Pons et al. (1994) reported. Thus, the presence of winter cereal surfaces could lead to increased aphid abundances on maize because of a possible concentration effect (Root 1973) in early seasons at small landscape scales. This trend was also reported by Gilabert et al. (2017), who showed that aphid populations increase in homogeneous landscapes dominated by cereals. Although the effect of non-crop habitats on the abundance of herbivorous insects has been found to be inconsistent (Chaplin-Kramer et al. 2011), the proportion of non-crop habitats had a positive effect in this study on the early-season aphid abundance at the three scales. The lack of infected grasses, as found in this study, as well as the higher species diversity in non-crop habitats than in other habitats, suggest that these are a source of aphids in the early season, although likely not viruliferous.

\subsection{Effects of landscape and field variables on maize potyvirus incidence}

It has been suggested that common single-scale analyses can underestimate the impact of humans on biodiversity, diseases and the environment (Cohen et al. 2016). In fact, we used an approach based on the proportion of cereals, alfalfa and noncrop habitats surrounding the sampled fields at three spatial scales to determine whether a high proportion of cereals in the landscape contribute to the risk of viral diseases. The most parsimonious models relating MDMV and SCMV incidences with the landscape and field variables are shown in Table 2. Only significant variables of the best model are shown. The most predictive model according to the AIC value for both viruses was at the $200 \mathrm{~m}$ scale. This small spatial scale mostly involves close field edges. These results are in concordance with those reported by Borer et al. (2010), who showed that local context provides the strongest explanation of disease risk variation in generalist viruses. Overall, the incidence of
MDMV was most influenced by field effects, whereas the SCMV incidence was most affected by landscape factors.

Field variables related to field management had strong effects on both viruses as Fig. 3a shows. All field variables used in the analysis had strong positive effects on MDMV, but only the planting date, the aphid abundance and the weed diversity of edges had positive effects on SCMV. Concretely, the planting date was the first and the weightiest field variable linked positively to the virus incidence in both virus models especially, in later planting dates (since week number 25) (Fig. 3b). The strong effect of late sowing maize resulted from spatialtemporal encounters of high aphid populations and high inoculum pressure. By contrast to the early planting where the only source of viruses is grass reservoirs, in late showing, source of viruses included also infected-maize planting earlier. This result is particularly relevant in our area and in other areas where maize is sown late after winter cereals have been harvested. We therefore note the necessity to review the adequacy of maize planting dates, especially for late sown maize. In addition, the important relationship between the plant species composition of edges and the potyvirus incidence indicates that edges are an important driver of infection at $200 \mathrm{~m}$ (Fig. 3b, graph of diversity of edges). Furthermore, when we grouped the information relating flora surveys by the type of edges, we found that the species diversity value was not different between edges, but plant cover was especially high in the edges of multiannual crops (for example, in the edges of alfalfa or in orchard ground covers) (Fig. 2a). This feature confirms that the importance of virus dispersal to maize fields could depend more on the cover and multiannual character of edge plant species cover than their diversity, especially in spring. Therefore, analyses of infection risk by potyviruses in the future must include the cover of non-abundant grass.

On the other hand, the percentage of non-crop habitats was a landscape variable that was very negatively related to the incidence of both viruses in all models, especially at $200 \mathrm{~m}$ (Fig. 3b, graph of non-crop habitat and Table 2). Thus, increased levels of human management that is associated with decreased habitat species diversity result in increased virus infection risk, as stated by Pagán et al. (2012) for virus epidemics. However, although biodiversity in non-crop habitats has been reported as a factor determining disease risk (Keesing et al. 2006; Pagán et al. 2012), few studies have focused on host plant-virus systems. Our results seem to follow the "dilution effect" hypothesis (Keesing et al. 2006), which means that an increase in plant species diversity in the landscape could decrease the overall disease risk by increasing the possibility that vectors will feed on noninfected plants.

The study area was a landscape dominated by winter and summer cereals, mainly maize (the maximum proportions for all sites were 87.05 at $200 \mathrm{~m}, 86.26$ at $500 \mathrm{~m}$ and 73.60 at 
a

\section{Maize Dwarf Mosaic Virus}

Variable importance

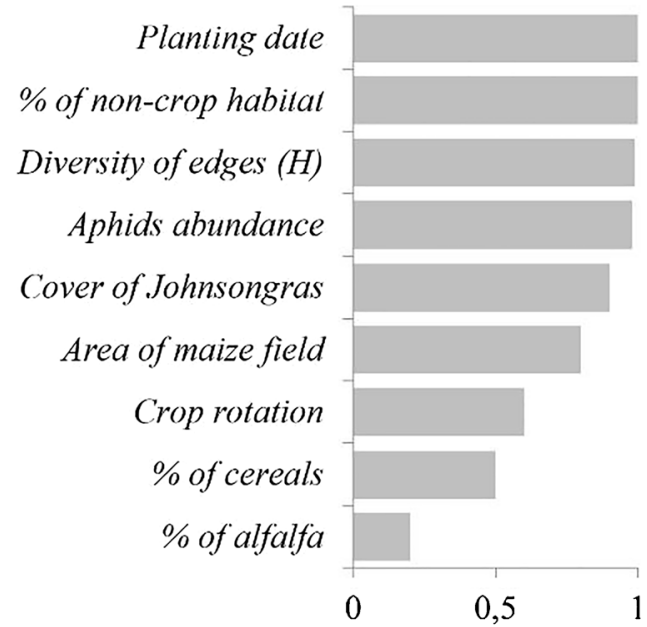

Sugarcane Mosaic Virus

Variable importance

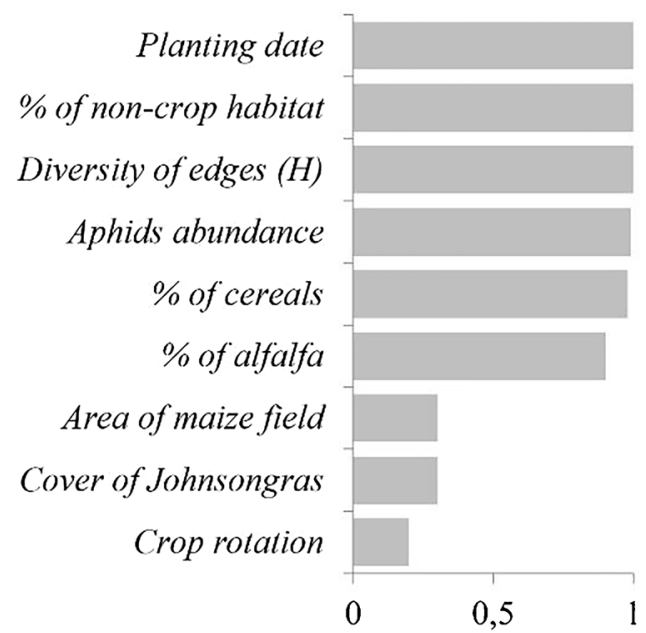

b
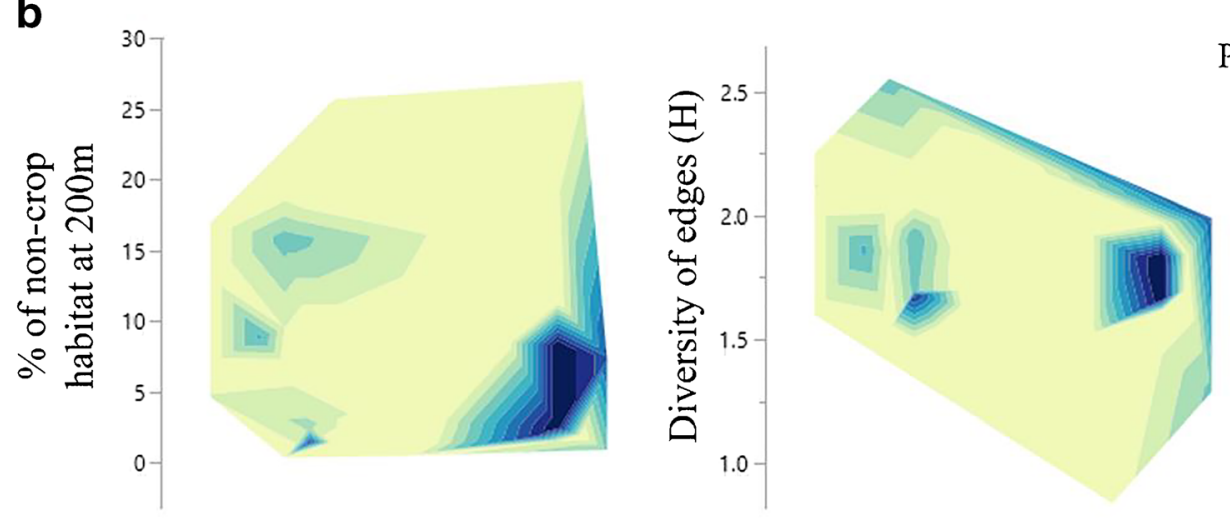

Potyvirus incidence
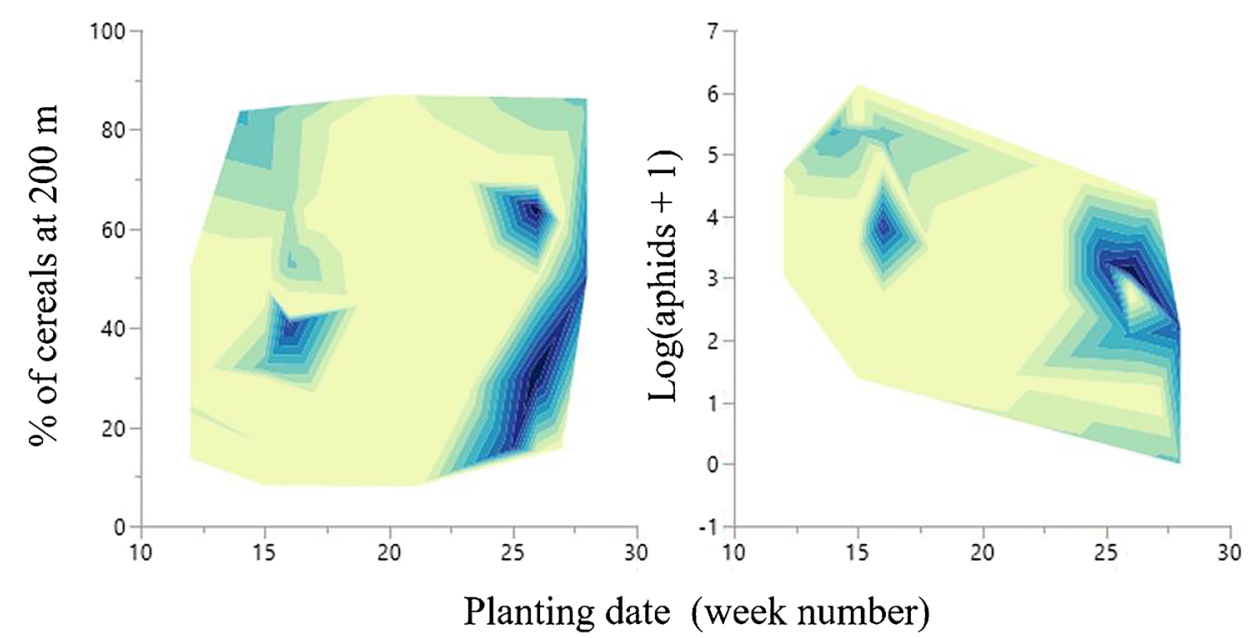

Fig. 3 a Graphs of relative importance of each predictor variable (sum of Akaike weights of the best models in which each variable appears) on virus incidence models at $200 \mathrm{~m}$. In the best models at $200 \mathrm{~m}$ for both viruses, the percentage of non-crop habitats, the maize planting date and the diversity of edges were strong predictors. b Contour plots show the response values and desirable operating conditions. The contour plot contains the following elements: predictors on the $\mathrm{X}$ (planting date) and $\mathrm{Y}$ (\% of non-crop habitats and \% of cereals at $200 \mathrm{~m}$, aphid abundance and $H$ of edges) axes. Contour lines connect points that have the same adjusted response value 
Table 2 Generalised linear mixed models used in multimodel inference to select the best effects model on aphid abundance, MDMV and SCMV incidence relating the influence of landscape and field variables. Models were fitted at three spatial scales from 200 to $1000 \mathrm{~m}$ around the sampled fields. Only significant variables in the best models $(\Delta \mathrm{AIC}<2)$ are presented. AIC values indicate little differences in support from data model

\begin{tabular}{|c|c|c|c|c|c|c|c|c|c|c|}
\hline & & $200 \mathrm{~m}$ & & & $500 \mathrm{~m}$ & & & $1000 \mathrm{~m}$ & & \\
\hline Scale & Variables & Estimate & $z$ value & $p$ value & Estimate & $z$ value & $p$ value & Estimate & $z$ value & $p$ value \\
\hline \multicolumn{11}{|c|}{ Aphid abundance } \\
\hline \multirow[t]{6}{*}{ Field } & (Intercept) & 3.46 & 5.45 & $<0.001$ & 3.45 & 5.15 & $<0.001$ & 3.45 & 5.15 & $<0.001$ \\
\hline & Planting date (weeks) & -0.56 & 3.16 & 0.002 & -0.48 & 3.42 & 0.001 & -0.48 & 3.42 & $<0.001$ \\
\hline & Area maize field (ha) & & & & & & & & & \\
\hline & Rotation (winter/summer cereal) & & & & & & & & & \\
\hline & $H$ in the edges & & & & & & & & & \\
\hline & Johnson grass plant cover & & & & & & & & & \\
\hline \multirow[t]{4}{*}{ Landscape } & Percentage of cereals & 0.24 & 1.73 & 0.058 & & & & & & \\
\hline & Percentage of alfalfa & & & & & & & & & \\
\hline & Percentage of non-crop habitats & 0.30 & 2.13 & 0.033 & 0.49 & 2.87 & 0.004 & 0.37 & 2.86 & 0.004 \\
\hline & Akaike information value (AIC) & 436.33 & & & 434.21 & & & 441.64 & & \\
\hline \multicolumn{11}{|c|}{ MDMV incidence } \\
\hline \multirow[t]{7}{*}{ Field } & (Intercept) & -2.47 & 2.89 & 0.004 & -2.30 & 3.77 & $<0.001$ & -2.24 & 4.34 & $<0.001$ \\
\hline & Planting date (weeks) & 0.97 & 8.93 & $<0.001$ & 0.97 & 8.84 & $<0.001$ & 0.97 & 8.25 & $<0.001$ \\
\hline & Area maize field (ha) & 0.39 & 2.90 & 0.004 & 0.20 & 2.17 & 0.030 & 0.29 & 2.90 & 0.004 \\
\hline & Rotation (winter/summer cereal) & 0.27 & 2.02 & 0.044 & & & & 0.44 & 3.10 & 0.002 \\
\hline & $H$ in the edges & 0.79 & 6.83 & $<0.001$ & 0.51 & 4.99 & $<0.001$ & 0.61 & 5.44 & $<0.001$ \\
\hline & Johnson grass plant cover & 0.37 & 2.84 & 0.005 & & & & 0.29 & 2.36 & 0.018 \\
\hline & Aphid (sum) & 0.44 & 3.22 & $<0.001$ & 0.34 & 3.02 & 0.003 & & & \\
\hline \multirow[t]{4}{*}{ Landscape } & Percentage of cereals & & & & -0.38 & 3.76 & $<0.001$ & -0.27 & 2.67 & 0.008 \\
\hline & Percentage of alfalfa & & & & & & & 0.55 & 6.26 & $<0.001$ \\
\hline & Percentage of non-crop habitats & -0.98 & 8.47 & $<0.001$ & -0.90 & 6.23 & $<0.001$ & -0.32 & 3.67 & $<0.001$ \\
\hline & Akaike information value (AIC) & 485.41 & & & 538.71 & & & 537.15 & & \\
\hline \multicolumn{11}{|c|}{ SCMV incidence } \\
\hline \multirow[t]{7}{*}{ Field } & (Intercept) & -2.54 & 2.35 & 0.019 & -2.35 & 3.00 & 0.003 & -2.15 & 2.87 & 0.004 \\
\hline & Planting date (weeks) & 0.97 & 10.33 & $<0.001$ & 0.97 & 10.29 & $<0.001$ & 0.97 & 10.40 & $<0.001$ \\
\hline & Area maize field (ha) & & & & & & & & & \\
\hline & Rotation (winter/summer cereal) & & & & & & & & & \\
\hline & $H$ in the edges & 0.96 & 8.30 & $<0.001$ & 0.80 & 7.03 & $<0.001$ & 0.70 & 6.29 & $<0.001$ \\
\hline & Johnson grass plant cover & & & & & & & & & \\
\hline & Aphid (sum) & 0.39 & 3.43 & $<0.001$ & 0.39 & 3.74 & $<0.001$ & & & \\
\hline \multirow[t]{4}{*}{ Landscape } & Percentage of cereals & 0.36 & 3.43 & $<0.001$ & -0.50 & 5.04 & $<0.001$ & -0.20 & 2.10 & 0.036 \\
\hline & Percentage of alfalfa & 0.30 & 2.71 & $<0.001$ & & & & 0.52 & 6.17 & $<0.001$ \\
\hline & Percentage of non-crop habitats & -0.98 & 8.52 & $<0.001$ & -0.87 & 7.56 & $<0.001$ & -0.27 & 3.42 & $<0.001$ \\
\hline & Akaike information value (AIC) & 523.98 & & & 561.16 & & & 584.29 & & \\
\hline
\end{tabular}

$1000 \mathrm{~m}$ ), with the relevant presence of non-crop habitats in some areas. Although at $200 \mathrm{~m}$ the percentage of cereals had positive effects on SCMV, in contrast to our expectations and as suggested by Rodríguez-Nevado et al. (2017), the high proportion of cereals did not amplify the virus incidence of MDMV and SCMV at large spatial scales (Fig. 3b, graph of \% of cereals). The positive relationship between the percentage of alfalfa in the landscape with both viruses at $1000 \mathrm{~m}$ and with SCMV at $200 \mathrm{~m}$ suggests that the durability and presence of grasses in the edges and within this crop result in a broad source of host plants of multiannual species, particularly Johnson grass, as mentioned above. 


\section{Conclusions}

Our results show for the first time the main drivers of potyvirus infection in maize crops by using a novel analysis methodology considering landscape and field variables at different spatial scales. We show that infections by the two potyviruses follow different patterns that are more predictive at a small spatial scale $(200 \mathrm{~m})$. The fact that the best spatial scale for both viruses is $200 \mathrm{~m}$ means that maize fields itself and close edges, that is, the local context is the strongest predictor of the risk of infection. While MDMV infection risk is more linked to field management than SCMV, infection risk of SCMV is more dependent than MDMV on the close field edges measured in this study as landscape variables. In addition, infection risk demonstrates a strong dependency on the proportion of non-crop habitats, the maize planting date, and the diversity of weeds in the edges. Moreover, Johnson grass is the main driver of infection by the two viruses, especially in maize fields shown late in coincidence with the more abundant flights of vectors. On the other hand, the use of more powerful tools to detect infected samples by SCMV could improve our understanding of the role of minor multiannual grasses in the epidemiology of the virus, especially in grasses growing in edges between alfalfa and cereal fields.

Overall, we report that in areas where generalist viruses are transmitted in a non-persistent manner, the local context is the most appropriate context to prevent virus infection. Thus, we recommend the following measures: (1) avoid late maize planting dates as much as possible to minimise infection risk, (2) integrate or keep non-crop habitats in the landscape in order to increase plant biodiversity and (3) confirm the convenience of the eradication of grass weeds, particularly Johnson grass, within the field and in maize edges.

Acknowledgements We are grateful to L. Serrano for his help during maize sampling and A. Juárez for weed species identification. We thank to the technicians from agricultural cooperatives for providing information on the management, and the landowners, for allowing us to access to their fields.

Contributions G.C.O. contributed to collect the landscape information, the insect abundance, grass and maize samples, analysed of the data, interpreted the results, and drafted the article. R.A. contributed to the design of the work, the collect insect data and drafted the article. M.A. contributed to the design of the collect maize and grass samples, and revised the final manuscript.

Funding information This study was funded by the Spanish Ministry of Economy, Industry and Competitiveness project AGL2014-53970-C2-1R and AGL2017-84127-R. G. Clemente-Orta was also funded by the grant BES-2015-072378 from the Ministry of Science, Innovation and Universities.

\section{Compliance with ethical standards}

Conflict of interest The authors declare that they have no conflict of interest.

\section{References}

Achon MA, Alonso-Dueñas N (2009) Impact of 9 years of Bt-maize cultivation on the distribution of maize viruses. Transgenic Res 18:387-397. https://doi.org/10.1007/s11248-008-9231-2

Achon MA, Serrano L, Alonso-Duenas N, Porta C (2007) Complete genome sequences of Maize dwarf mosaic and Sugarcane mosaic virus isolates coinfecting maize in Spain. Archives of virology, 152(11):2073-2078. https://doi.org/10.1007/s00705-007-1042-x

Achon MA, Sobrepere M (2001) Incidence of potyviruses in commercial maize fields and their seasonal cycles in Spain., Zeitschrift für Pflanzenkrankheiten und Pflanzenschutz. Ulmer 108(4):399-406

Achon MA, Medina V, Shanks M, Markham P, Lomonossoff GP (1994) Characterisation of a maize-infecting potyvirus from Spain. Eur J Plant Pathol 100:157-165. https://doi.org/10.1007/BF01876248

Adams A, Clark M (1977) Characteristics of the microplate method of enzyme-linked immunosorbent assay for the detection of plant viruses. J Gen Virol 34:475-483. https://doi.org/10.1099/0022-131734-3-475

Anderson PK, Cunningham AA, Patel NG, Morales FJ, Epstein PR, Daszak P (2004) Emerging infectious diseases of plants: pathogen pollution, climate change and agrotechnology drivers. Trends Ecol Evol 19:535-544. https://doi.org/10.1016/j.tree.2004.07.021

Asín L, Pons X (1999) Effects of soil insecticide treatments on maize aphids and aphid predators in Catalonia. Crop Prot 18:389-395. https://doi.org/10.1016/S0261-2194(99)00039-3

Bartoń K (2018) Package "MuMIn" title: multi-model inference. R package version: 1.43.6 https://cran.r-project.org/web/packages/MuMIn/ MuMIn.pdf

Biek R, Real LA (2010) The landscape genetics of infectious disease emergence and spread. Mol Ecol 19:3515-3531. https://doi.org/10. 1111/j.1365-294X.2010.04679.x

Borer ET, Seabloom EW, Mitchell CE, Power AG (2010) Local context drives infection of grasses by vector-borne generalist viruses. Ecol Lett 13:810-818. https://doi.org/10.1111/j.1461-0248.2010.01475. $\mathrm{x}$

Braun-Blanquet J (1979) Fitosociología. Bases para el estudio de las comunidades vegetales. Ediciones Blume, Madrid

Campbell MJ, Swinscow TDV (2009) Statistics at Square One, 11th edn. WileyBlackwell, Chichester, West Sussex

Chaplin-Kramer R, O’Rourke ME, Blitzer EJ, Kremen C (2011) A metaanalysis of crop pest and natural enemy response to landscape complexity. Ecol Lett 14:922-932. https://doi.org/10.1111/j.1461-0248. 2011.01642.x

Clemente-Orta G, Madeira F, Batuecas I, Sossai S, Juárez-Escario A, Albajes R (2020) Changes in landscape composition influence the abundance of insects on maize: the role of fruit orchards and alfalfa crops. Agric Ecosyst Environ 291:106805. https://doi.org/10.1016/j. agee.2019.106805

Cohen JM, Civitello DJ, Brace AJ, Feichtinger EM, Ortega CN, Richardson JC, Sauer EL, Liu X, Rohr JR (2016) Spatial scale modulates the strength of ecological processes driving disease distributions. Proc Natl Acad Sci 113:E3359-E3364. https://doi.org/ $10.1073 /$ pnas. 1521657113

Ford RE, Tosic M D D (1989) Shukla: maize dwarf mosaic virus. CMI/ AAB Descriptions of Plant Viruses No.341.

García-Arenal F, McDonald BA (2003) An analysis of the durability of resistance to plant viruses. Phytopathology 93:941-952. https://doi. org/10.1094/phyto.2003.93.8.941

Gilabert A, Gauffre B, Parisey N, Le Gallic JF, Lhomme P, Bretagnolle V, Dedryver CA, Baudry J, Plantegenest M (2017) Influence of the surrounding landscape on the colonization rate of cereal aphids and phytovirus transmission in autumn. J Pest Sci 2004(90):447-457. https://doi.org/10.1007/s10340-016-0790-3 
Hohmann F, Fuchs E, Grüntzig M (1998) Untersuchungen zum wirtskreis des sugarcane mosaic potyvirus (scmv) und des maize dwarf mosaic potyvirus (MDMV) in Deutschland. Arch Phytopathol Plant Protect 31:507-518. https://doi.org/10.1080/ 03235409809383264

Keesing F, Holt RD, Ostfeld RS (2006) Effects of species diversity on disease risk. Ecol Lett 9:485-498. https://doi.org/10.1111/j.14610248.2006.00885.x

Malmstrom CM, Melcher U, Bosque-Pérez NA (2011) The expanding field of plant virus ecology: historical foundations, knowledge gaps, and research directions. Virus Res 159(2):84-94. https://doi.org/10. 1016/j.virusres.2011.05.010

McLeish M, Sacristán S, Fraile A, Garcia-Arenal F (2017) Scale dependencies and generalism in host use shape virus prevalence. Proc $\mathrm{R}$ Soc B Biol Sci 284:20172066. https://doi.org/10.1098/rspb.2017. 2066

Meentemeyer RK, Haas SE, Václavík T (2012) Landscape epidemiology of emerging infectious diseases in natural and human-altered ecosystems. Annu Rev Phytopathol 50:379-402. https://doi.org/10. 1146/annurev-phyto-081211-172938

Moradi Z, Nazifi E, Mehrvar M (2017) Occurrence and evolutionary analysis of coat protein gene sequences of Iranian isolates of sugarcane mosaic virus. The plant pathology journal 33(3):296-306. https://doi.org/10.5423/PPJ.OA.10.2016.0219

Oertel U, Fuchs E, Hohmann F (1999) Differentiation of isolates of sugarcane mosaic potyvirus (SCMV) on the basis of molecular, serological and biological investigations/Differenzierung von Isolateti des Sugarcane mosaic potyvirus (SCMV) auf der Grundlage molekularer, serologischer und biologischer Untersuchungen. Zeitschrift für Pflanzenkrankheiten und Pflanzenschutz/J Plant Dis Protect:304-313
Pagán I, González-Jara P, Moreno-Letelier A, Rodelo-Urrego M, Fraile A, Piñero D, García-Arenal F (2012) Effect of biodiversity changes in disease risk: exploring disease emergence in a plant-virus system. PLoS Pathog 8:47. https://doi.org/10.1371/journal.ppat.1002796

Peerzada AM, Ali HH, Hanif Z, Bajwa AA, Kebaso L, Frimpong D, Iqbal N, Namubiru H, Hashim S, Rasool G, Manalil S, van der Meulen A, Chauhan BS (2017) Eco-biology, impact, and management of Sorghum halepense (L.) Pers. Biol. Invasions 1-19. doi:https://doi. org/10.1007/s10530-017-1410-8

Pons X, Asín L, Comas J, Albajes R (1994) Las especies de pulgones del maiz. Instituto Nacional de Investigacion y Tecnologia Agraria y Alimentaria, Madrid (España). Fuera de Serie 2:125-129

Ripley B (2019) Package "MASS." title: support functions and datasets for Venables and Ripley's MASS. R package version: 7.3-51.4 https://cran.r-project.org/web/packages/MASS/MASS.pdf

Rodríguez-Nevado C, Montes N, Pagán I (2017) Ecological factors affecting infection risk and population genetic diversity of a novel potyvirus in its native wild ecosystem. Front Plant Sci 8:1958. https://doi.org/10.3389/fpls.2017.01958

Root RB (1973) Organization of a plant-arthropod association in simple and diverse habitats: the fauna of collards (Brassica oleracea). Ecol Monogr 43:95-124. https://doi.org/10.2307/1942161

Stukenbrock EH, McDonald BA (2008) The origins of plant pathogens in agro-ecosystems. Annu Rev Phytopathol 46:75-100. https://doi.org/ 10.1146/annurev.phyto.010708.154114

Teakle DS, Shukla DD, Ford RE (1989) Sugarcane mosaic virus CMI/ $\mathrm{AAB}$ descriptions of plant viruses, 34 .

Publisher's note Springer Nature remains neutral with regard to jurisdictional claims in published maps and institutional affiliations. 